\title{
Occurrence and detection of lesser known viruses and phytoplasmas in stone fruit orchards in Poland
}

\author{
Mirostawa Cieślińska, Halina Morgaś
}

Research Institute of Pomology and Floriculture Pomologiczna 18, 96-100 Skierniewice, Poland e-mail: Miroslawa.Cieslinska@insad.pl

\begin{abstract}
A survey was carried out on 38 commercial and experimental stone fruit orchards located in major growing areas of stone fruit trees in Poland to determine the incidence of lesser known viruses and phytoplasmas. Leaf samples from 145 sweet cherry and 102 sour cherry trees were tested for Little cherry virus 1 (LChV-1), Little cherry virus 2 (LChV-2), Cherry green ring mottle virus (CGRMV), Cherry mottle leaf virus (CMLV), and Cherry necrotic rusty mottle virus (CNRMV) using RT-PCR. Sixty samples collected from peach and 20 apricot trees were also tested for CGRMV. Eleven out of 145 sweet cherry and three out of 102 sour cherry trees were infected by LChV-1. CGRMV was detected in 10 sweet cherry, four sour cherry, 14 peach and two apricot trees. No LChV-2, CMLV and CNRMV were detected in any of the tested trees. Phloem tissue from samples of shoots collected from 145 sweet cherry, 102 sour cherry, 128 peach, 37 apricot, five nectarine and 20 European as well as Japanese plum trees were tested for phytoplasmas. The nested PCR of the extracted DNA with universal and specific primer pairs showed the presence of phytoplasmas in six sweet cherry, three sour cherry, nine peach, four apricot, one nectarine and three Japanese plum trees. The RFLP patterns of 16S rDNA fragments after digestion with RsaI, MseI, AluI, and SspI endonucleases indicated that selected stone fruit trees were infected by two distinct phytoplasmas belonging to the apple proliferation group. The stone fruit trees infected by LChV-1, CGRMV and phytoplasmas were grown in orchards localised in all seven regions.
\end{abstract}

Key words: CGRMV, CMLV, CNRMV, LChV-1, LChV-2, PCR/RFLP, phytoplasmas

\begin{abstract}
Abbreviations:
RT-PCR - reverse transcription-polymerase chain reaction; RFLP - restriction fragment length polymorphism; PNRSV - Prunus necrotic ring spot virus; PDV - Prune dwarf virus; LChD - Little cherry disease; LChV - Little cherry virus; CGRMV - Cherry green ring mottle virus; CMLV - Cherry mottle leaf virus; CNRMV - Cherry necrotic rusty mottle virus; 'Ca. P. prunorum' - 'Candidatus Phytoplasma prunorum'; 'Ca. P. mali' 'Candidatus Phytoplasma mali'; 'Ca. P. pyri' - 'Candidatus Phytoplasma pyri'; DNA - deoxyribonucleic acid; cDNA - complementary deoxyribonucleic acid; AP - apple proliferation; rRNA - ribosomal ribonucleic acid
\end{abstract}

\section{INTRODUCTION}

Stone fruit trees are the hosts of more than 30 viruses and virus-like pathogens. Among them, Prunus necrotic ring spot virus (PNRSV) and Prune dwarf virus (PDV) are the most common worldwide and also widely present in Polish orchards. One of the lesser known pathogens in Poland are Little cherry virus 1,2 or 3 (LChV-1, LChV-2 or LChV-3) causing Little cherry disease (LChD). Sweet cherry fruits of some cultivars affected by LChV are small, pointed, imperfectly coloured, and tasteless, and leaves show a red-brown colouration of the surface (Welsh and Cheney 1976). Cherry green ring 
mottle virus (CGRMV) infects sweet cherry, sour cherry, peach, apricot and other Prunus species, causing yellowing and dark mottling of the sour cherry trees leaves, whereas sweet cherry trees are latently infected (Desvignes 1999). Cherry mottle leaf virus (CMLV) induces irregular and chlorotic mottling, leaf distortion and puckering, reduced yield, and smaller and tasteless fruits (James and Mukerji 1993). Trees infected with Cherry necrotic rusty mottle virus (CNRMV) show brown, angular necrotic spots, shot holes on the leaves, gum blisters and necrosis of the bark (Wadley and Nyland 1976).

Several phytoplasmas may infect stone fruit trees, but the most common in Europe is 'Candidatus Phytoplasma prunorum' ('Ca. P. prunorum'), associated with European stone fruit yellows disease. This phytoplasma is closely related to 'Candidatus Phytoplasma mali' ('Ca. P. mali') and 'Candidatus Phytoplasma pyri' (' $C a$. P. pyri'), which cause apple proliferation and pear decline diseases, respectively (Seemüller and Schneider 2004).

The aim of this study was to determine the incidence of phytoplasmas and lesser known viruses in stone fruit trees grown in commercial and experimental orchards in several regions of Poland as well as the detection of cDNA fragments of the viruses using RT-PCR and the identification of $16 \mathrm{~S}$ rRNA gene fragments of the phytoplasmas using the PCR/RFLP method.

\section{MATERIAL AND METHODS}

Surveys were conducted in June and July 20072009 in 38 commercial and experimental stone fruit orchards from seven geographical locations within Poland (Poznan, Wroclaw, Warsaw, Lodz, Lublin, Kielce, and Zielona Gora regions). The orchards' area ranged from 0.5 to 3 ha and the age of the trees ranged from 6 to 15 years. To test the trees for virus presence, leaf samples were collected separately from 4-22 symptomatic trees from each orchard dependent on its area. There were 145 sweet cherry and 102 sour cherry trees tested for Cherry green ring mottle virus (CGRMV) and Cherry necrotic rusty mottle virus (CNRMV), both unassigned species in the Flexiviridae family, Little cherry virus 1 (LChV-1), an unassigned species in the Closteroviridae family, Little cherry virus 2 (LChV2) classified as Ampelovirus in the Closteroviridae family, and Cherry mottle leaf virus (CMLV), a Trichovirus species in the Flexiviridae family (Fauquet et al. 2005). Sixty peach and 20 apricot trees showing disease symptoms were also tested for CGRMV. Samples of shoots from 145 sweet cherry, 102 sour cherry, 128 peach, 37 apricot, five nectarine and 20 European as well as Japanese plum trees were collected to be tested for phytoplasmas (Table 1).

Nucleic acids extracted from leaves using a RNeasy Plant Mini Kit (Qiagen, Hilden, Germany) were subjected to a reverse transcriptionpolymerase chain reaction (RT-PCR). Primer pairs GRMV7956/GRMV8316 (Rott and Jelkmann 2001 a), LCV1U16390/LCV1L16808 (Rott and Jelkmann 2001 b), LCVUP2/LCVLO2 (Rott and Jelkmann 2001 b), CML13A/CML4A (James et al. 1999) and NRM48U/NRM48L (Rott and Jelkmann 2001 a) were used for the amplification of CGRMV, LChV-1, LChV-2, CMLV, and CNRMV genome fragments, respectively.

Nucleic acids extracted from phloem tissue using a DNeasy Plant Mini Kit (Qiagen, Hilden, Germany) were subjected to PCR with universal primers P1/P7 (Deng and Hiruki 1991, Schneider et al. 1995). The products of $\mathrm{P} 1 / \mathrm{P} 7$ amplifications were diluted 1:40 with sterile, deionized water and used as templates in the nested PCR with the universal primers R16F2n/R16R2 (Gundersen and Lee 1996), as well as primers specific for the 16SrI, $16 \mathrm{SrIII}, 16 \mathrm{SrV}$, and $16 \mathrm{SrX}$ groups (Kirkpatrick et al. 1994, Lee et al. 1994, 1995). For the analysis of the amplification products, 81 of the post nested PCR mixtures were evaluated by electrophoresis in a $1.5 \%$ agarose gel. The DNA was visualised under UV light after staining with ethidium bromide. The molecular weight of the PCR products was estimated by comparison with 100 bp DNA ladder (Fermentas, Vilnius, Lithuania).

Products of the nested PCR primed by R16F2n/ R16R2 from 10 tree samples were subjected to restriction fragment length polymorphism analyses (RFLP) using RsaI, MseI, AluI, and $S s p \mathrm{I}$ endonucleases (Fermentas, Vilnius, Lithuania) according to the manufacturer's instructions. DNA of phytoplasmas belonging to the apple proliferation group $16 \mathrm{SrX}$ subgroups $\mathrm{A}, \mathrm{B}$, and $\mathrm{C}$ were applied as positive controls. The generated restriction patterns were analysed by electrophoresis in $8 \%$ polyacrylamide gels. The resulting RFLP patterns were compared with profiles for positive controls and those obtained for the reference strains (Lee et al. 1998, Seemüller and Schneider 2004).

\section{RESULTS AND DISCUSSION}

Only two sweet cherry trees showed reddish and brown discoloration of the leaves and small, pale, pointed fruits characteristic for little cherry disease 
(Welsh and Cheney 1976). Symptoms of other virus diseases were not observed. Some of the surveyed trees showed chlorotic leaf roll, reduction of growth and dieback. Similar symptoms were described as characteristic for phytoplasmal diseases (Lederer and Seemüller 1992). Previous studies showed the presence of LChV-1, LChV-2, CGRMV and phytoplasmas in Poland mostly in trees grown in experimental orchards or germplasm collections (Cieślińska et al. 2004, Komorowska and Cieślińska 2004, 2005, 2008).

Eleven out of 145 sweet cherry and three out of 102 sour cherry trees were infected by LChV1 (Tab. 1, Fig. 1). CGRMV was detected in 10 sweet cherry, four sour cherry, 14 peach and two apricot trees assayed during this study (Fig. 2). LChV-2, CMLV or CNRMV was not detected in any of the tested trees. A high incidence of lesser known viruses was reported in other countries. In the Mediterranean, reports occasionally included CGRMV (Zhang et al. 2000, Gentit et al. 2002) and CNRMV (Gentit et al. 2002) but a relatively high incidence of both viruses was noted in Serbia (Mandic et al. 2007). In Japan, LChV-1, LChV-2, CGRMV and CNRMV were detected depending on the virus in $14-92 \%$ of tested sweet cherry trees grown in several provinces (Isogai et al. 2004). LChV-1, CGRMV and CNRMV were also detected in California, USA (Sabanadzovic et al. 2005).

The results of nested PCR with R16F2n/R16R2 universal primers indicated that a total of 26 out of the 437 tested stone fruit trees were infected with phytoplasmas (mean infection rate 5.9\%), among them: six sweet cherry, three sour cherry, nine peach, four apricot, one nectarine and three Japanese plum trees. No PCR product was obtained with DNA from a healthy tree. The result of nested PCR with $\mathrm{R} 16(\mathrm{X}) \mathrm{F} 1 / \mathrm{R} 1$ primers indicated that positive tested trees were infected by phytoplasmas belonging to the apple proliferation (AP) group (16SrX). No positive results were obtained in reaction with primer pairs specific for any of the 16SrI, 16SrIII and $16 \mathrm{SrV}$ phytoplasma groups.

RFLP results confirmed the infection of sweet cherry (3), sour cherry (1), peach (3), apricot (1) and plum (1) trees by phytoplasmas classified to the apple proliferation group (Fig. 3). The digestion profiles of phytoplasmal $16 \mathrm{~S}$ rRNA gene fragments from nine tested trees were indistinguishable from restriction patterns for the reference strain of 'Candidatus Phytoplasma prunorum' classified to the subgroup 16SrX-B (Lee et al. 1998, Seemüller and Schneider 2004). During our study, ' $C a$. P. prunorum' was detected for the first time in naturally infected stone fruit trees in Poland.

Favourable climate conditions for the spreading of phytoplasmas and the possibility of the occurrence of its vector may lead to an increased epidemiological risk of ' $\mathrm{Ca}$. P. prunorum' in Poland. European stone fruit yellows caused by ' Candidatus Phytoplasma prunorum' has been reported in many countries but its incidence in apricot, peach and plum orchards is relatively high in southern Europe. This phytoplasma was detected in sweet cherry, peach,

Table 1. Relative incidence of LChV-1, CGRMV and phytoplasmas detected in stone fruit trees in seven regions of Poland based on RT-PCR and PCR results

\begin{tabular}{|c|c|c|c|c|c|c|c|c|}
\hline \multirow{3}{*}{$\begin{array}{l}\text { Pathogen/ } \\
\text { Species }\end{array}$} & \multicolumn{8}{|c|}{ Surveyed orchards/Positive samples/Tested samples (No.) } \\
\hline & \multicolumn{8}{|c|}{ Region } \\
\hline & Poznan & Wroclaw & Warsaw & Lodz & Lublin & Kielce & Z. Gora & Total \\
\hline \multicolumn{9}{|l|}{ LChV-1 } \\
\hline Sweet cherry & $1 / 1 / 12$ & $2 / 1 / 23$ & $1 / 1 / 22$ & $2 / 2 / 23$ & $2 / 3 / 22$ & $2 / 3 / 23$ & $2 / 0 / 20$ & $12 / 11 / 145$ \\
\hline Sour cherry & $2 / 2 / 16$ & $2 / 0 / 17$ & $2 / 0 / 16$ & $2 / 0 / 16$ & $2 / 0 / 17$ & $2 / 1 / 12$ & $1 / 0 / 8$ & $13 / 3 / 102$ \\
\hline \multicolumn{9}{|l|}{ CGRMV } \\
\hline Sweet cherry & $1 / 2 / 12$ & $2 / 0 / 23$ & $1 / 0 / 22$ & $2 / 3 / 23$ & $2 / 3 / 22$ & $2 / 0 / 23$ & $2 / 2 / 20$ & $12 / 10 / 145$ \\
\hline Sour cherry & $2 / 1 / 16$ & $2 / 0 / 17$ & $2 / 1 / 16$ & $2 / 1 / 16$ & $2 / 0 / 17$ & $2 / 1 / 12$ & $1 / 0 / 8$ & $13 / 4 / 102$ \\
\hline Peach & $1 / 2 / 8$ & $2 / 3 / 18$ & $\mathrm{NT}^{*}$ & NT & $2 / 5 / 20$ & $2 / 4 / 14$ & NT & $7 / 14 / 60$ \\
\hline Apricot & NT & $1 / 1 / 4$ & $1 / 0 / 4$ & $1 / 0 / 4$ & $1 / 1 / 5$ & $1 / 0 / 3$ & NT & $5 / 2 / 20$ \\
\hline \multicolumn{9}{|l|}{ Phytoplasma } \\
\hline Sweet cherry & $1 / 0 / 12$ & $2 / 2 / 23$ & $1 / 0 / 22$ & $2 / 3 / 23$ & $2 / 1 / 22$ & $2 / 0 / 23$ & $2 / 0 / 20$ & $12 / 6 / 145$ \\
\hline Sour cherry & $2 / 2 / 16$ & $2 / 0 / 17$ & $2 / 0 / 16$ & $2 / 1 / 16$ & $2 / 0 / 17$ & $2 / 0 / 12$ & $1 / 0 / 8$ & $13 / 3 / 102$ \\
\hline Peach & $2 / 1 / 14$ & $3 / 2 / 26$ & $1 / 1 / 8$ & $1 / 1 / 11$ & $3 / 2 / 29$ & $3 / 1 / 28$ & $1 / 1 / 12$ & $14 / 9 / 128$ \\
\hline Apricot & $1 / 1 / 4$ & $1 / 0 / 4$ & $1 / 0 / 4$ & $1 / 0 / 4$ & $2 / 1 / 9$ & $3 / 2 / 12$ & NT & $9 / 4 / 37$ \\
\hline Plum & $1 / 0 / 5$ & NT & NT & $1 / 2 / 8$ & NT & NT & $1 / 1 / 7$ & $3 / 3 / 20$ \\
\hline Nectarine & $1 / 0 / 1$ & NT & NT & $1 / 0 / 1$ & NT & $1 / 1 / 3$ & NT & $3 / 1 / 5$ \\
\hline
\end{tabular}

*NT - not tested 


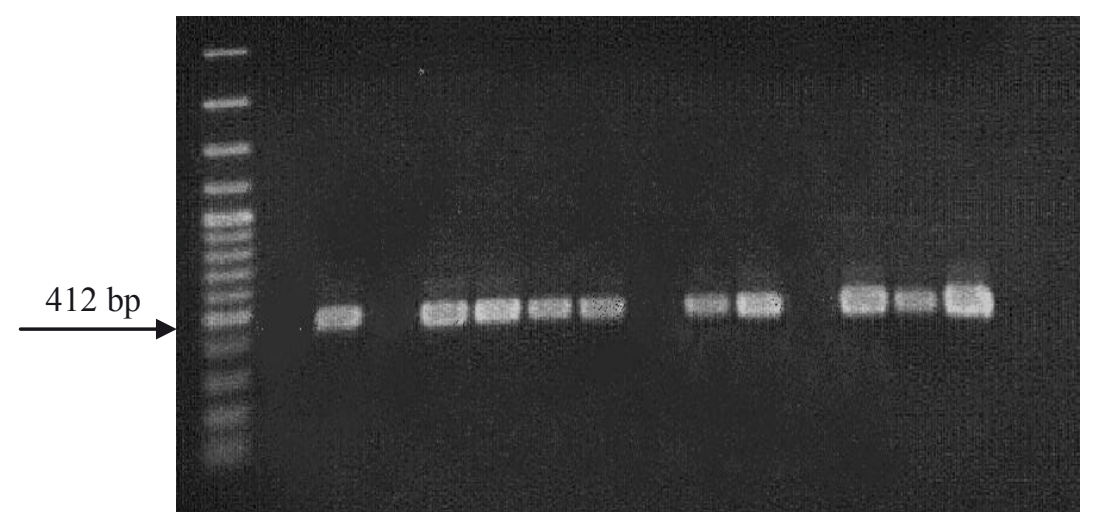

$\begin{array}{llllllllllllllll}\mathrm{L} & 1 & 2 & 3 & 4 & 5 & 6 & 7 & 8 & 9 & 10 & 11 & 12 & 13 & 14 & 15\end{array}$

Figure 1. Agarose gel electrophoresis of RT-PCR products obtained with primers LCV1U16390/LCV1L16808 specific for LChV-1. L - 100 bp DNA ladder; 1 - sample of healthy cherry; 2 - positive control; 3, 5, 7, 9, 10, 12, 13, 14 - sweet cherry trees; $4,6,8,11,15$ - sour cherry trees

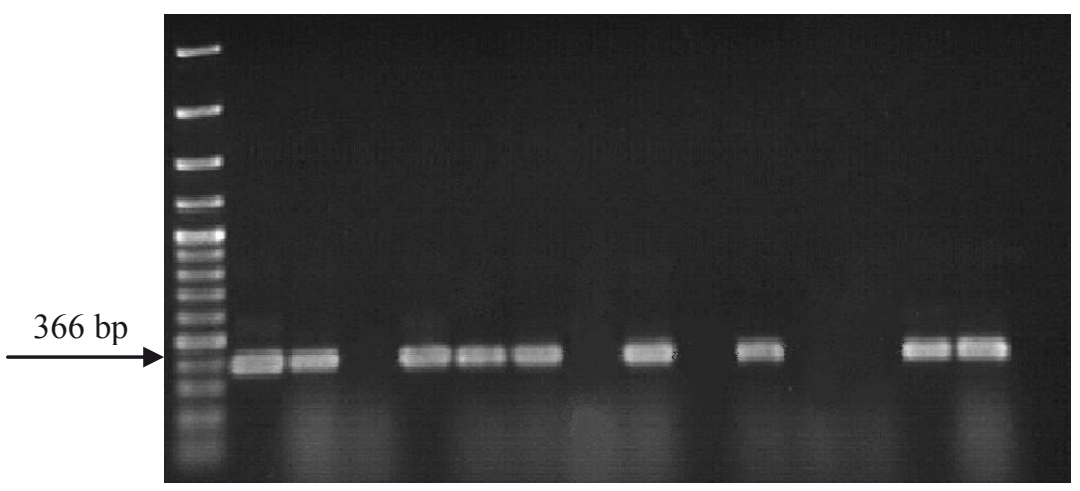

$\begin{array}{llllllllllllllll}\mathrm{L} & 1 & 2 & 3 & 4 & 5 & 6 & 7 & 8 & 9 & 10 & 11 & 12 & 13 & 14 & 15\end{array}$

Figure 2. Agarose gel electrophoresis of RT-PCR products obtained with primers GRMV7956/GRMV8316 specific for CGRMV. L - 100 bp DNA ladder; 1, 2, 6, 11, 13 - sweet cherry; 3, 4, 5, 12 - peach; 7, 8 - sour cherry; 9, 10 apricot; 14 - positive control; 15 - sample of healthy cherry
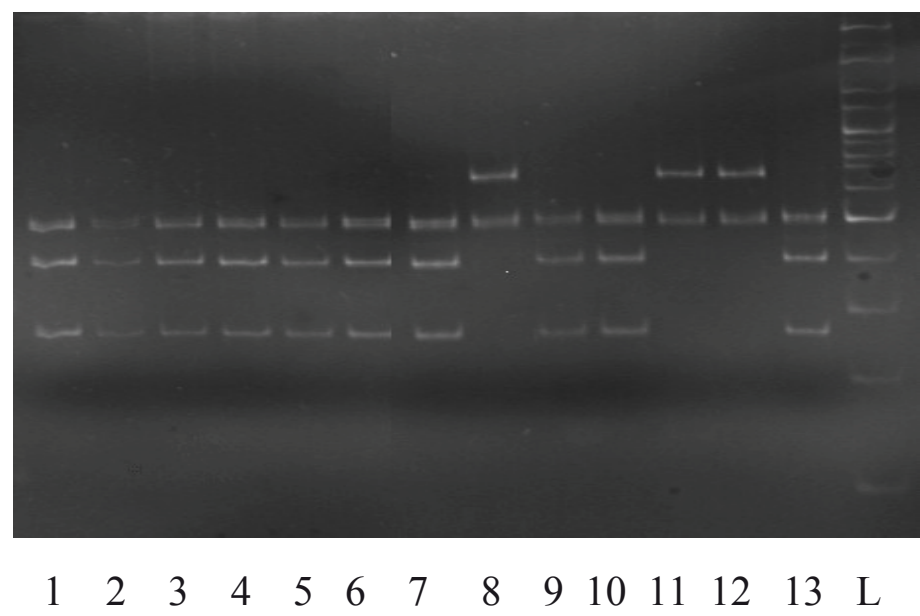

Figure 3. RFLP profiles with $R s a$ I enzyme after digestion of $1.2 \mathrm{kbp}$ fragments of $16 \mathrm{~S}$ rDNA amplified by PCR with $\mathrm{R} 16 \mathrm{~F} 2 \mathrm{n} / \mathrm{R} 16 \mathrm{R} 2$ primers from phytoplasmas infecting stone fruit trees. L - $100 \mathrm{bp}$ DNA ladder, 1, 2, 4-peach; 3 - sour cherry; 6, 10 - sweet cherry; 7 - Japanese plum; 8 - sweet cherry 'Kordia I/8'; 9 - apricot; 11 - 16SrX-A reference strain; $12-16 \mathrm{SrX}-\mathrm{C}$ reference strain; $13-16 \mathrm{SrX}-\mathrm{B}$ reference strain 
apricot and Japanese plum in Italy (Paltrinieri et al. 2001, Poggi Pollini et al. 2001), Spain (Laviña et al. 2004) and the Czech Republic (Navratil et al. 2001, Fialova et al. 2004), in apricot, peach, plum and amygdalus in Germany (Lederer and Seemüller 1992, Jarausch et al. 2008), in apricot and Japanese plum in Albania (Myrta et al. 2003) and in southern England (Davies and Adams 2000), as well as in apricot in France (Morvan et al. 1988) and Austria (Laimer da Camara Machado et al. 2001). The incidence of 'Candidatus Phytoplasma prunorum' depends on the region and species of the tested tree. Its relatively high incidence was noted in apricot (about $80 \%$ of infected trees) in some regions of Germany (Jarausch et al. 2008) and in plum (25$78 \%$ of infected trees) grown in several orchards in the Catalonia region of Spain (Laviña et al. 2004).

In our study, the profile for phytoplasma from 'Kordia I/8' sweet cherry from one of the orchards localised in the Lodz region was indistinguishable from the restriction pattern for 'Candidatus Phytoplasma pyri' (pear decline phytoplasma, subgroup $16 \mathrm{SrX}-\mathrm{C}$ ) after using the RsaI enzyme. It is the first evidence of the occurrence of this phytoplasma in Poland. Our findings support a postulation that pear decline and apple proliferation phytoplasmas do not seem to be limited only to pome fruit trees. Nested PCR/RFLP analyses showed the presence of 'Candidatus Phytoplasma pyri' in sweet cherry in Italy (Paltrinieri et al. 2001) and peach in the Czech Republic (Navratil et al. 2001, Fialova et al. 2004). In turn, RFLP profiles corresponding to the 'Candidatus Phytoplasma mali' reference strain were found in Japanese plum (Lee et al. 1995) and in peach (Paltrinieri et al. 2001) in Italy as well as in sweet cherry in the Czech Republic (Navratil et al. 2001). It is known that stone fruit species can be affected also by phytoplasmas belonging to other groups.

\section{ACKNOWLEDGEMENTS}

The research was partly supported by the Ministry of Science and Education, grant No 2P0 6A02830.

\section{REFERENCES}

CieŚlińska M., Morgaś H., Jakubowski T., 2004. Phytoplasma diseases of stone fruit trees in Poland. Acta Hort. 657: 523-526.

Davies D.L., Adams A.N., 2000. European stone fruit yellows phytoplasmas associated with a decline disease of apricot in southern England. Plant Pathol. 49: 635-639.
Deng S., Hiruki C., 1991. Genetic relatedness between two nonculturable mycoplasmalike organisms revealed by nucleic acid hybridization and polymerase chain reaction. Phytopathol. 81: 14751479.

Desvignes J.C., 1999. Virus diseases of fruit trees. CTIFL. Paris, France.

Fauquet C.M., Mayo M.A., Maniloff J., Desselberger U., Ball L.A., (eds), 2005. Virus taxonomy. Eighth Report of the International Committee of Taxonomy of Viruses. Elsevier Academic Press, San Diego.

Fialová R., Navrátil M., VÁlová P., Lauterer P., Kocourek F., Poncarová-VoráčKová Z., 2004. Epidemiology of European stone fruit yellows phytoplasma in the Czech Republic. Acta Hort. 657: 483-487.

Gentit P., Foissac X., Svanella-Dumas L., Peypelut M., Macquaire G., Candresse T., 2002. Molecular characterization of foveaviruses associated with the cherry necrotic mottle leaf disease and complete sequencing of an European isolate of cherry green ring mottle virus. Arch. Virol. 147(5): 1033-1042.

GundERSEN D.E., LEE I.-M., 1996. Ultrasensitive detection of phytoplasmas by nested-PCR assays using two universal primers. Phytopath. Medit. 35: 144-151.

Isogai M., Aoyagi J., Nakagawa M., Kubodera Y., Satoh K., Katoh T., Inamori M., Yamashita K., Yoshikawa N., 2004. Molecular detection of five cherry viruses from sweet cherry trees in Japan. J. Gen. Plant Pathol. 70: 288-291.

JAmes D., Mukerus S., 1993. Mechanical transmission, identification, and characterization of virus associated with mottle leaf in cherry. Plant Dis. 77: 271-275.

James D., Jelkmann W., Upton C., 1999. Specific detection of cherry mottle leaf virus using digoxigenin-labelled cDNA probes and RT-PCR. Plant Dis. 83: 235-239.

Jarausch B., Mühlenz I., Beck A., Lampe I., Harzer U., JARAUSCH W., 2008. Epidemiology of European Stone Fruit Yellows in Germany. Acta Hort. 781: 417-422.

Kirkpatrick B.C., Smart C.D., Gardner S.L, Gao J.-L., Ahrens U., Mäurer R., Schneider B., Lorenz K.-H., SeEmüller E., Harrison N.A., Namba S., Daire X., 1994. Phylogenetic relationships of plant pathogenic MLOs established by 16/23S rDNA spacer sequences. IOM Lett. 2: 228-229.

Komorowska B., CieŚlińska M., 2004. First report of Cherry virus $A$ and Little cherry virus-1 in Poland. Plant Dis. 88: 909.

Komorowska B., Cieślińska M., 2005. First report of Cherry green ring mottle virus in Poland. Plant Dis. 89(12): 1363.

Komorowska B., CieŚlińsKa M., 2008. First report of Little cherry-2 virus on sweet cherry in Poland. Plant Dis. 92(9): 1366.

Laimer Da Camara Machado M., Paltrinieri S., Panzer V., Arthofer W., Strommer S., Martini M., Pondrelli M., Bertaccini A., 2001. Presence of 
European Stone Fruit Yellows (ESFY or 16SrX-B) phytoplasma in apricots in Austria. Plant Pathol. 50: 130-135.

Laviña A., Sabaté J., García-Chapa M., Batlle A., Torres E., 2004. Occurrence and Epidemiology of European Stone Fruit Yellows Phytoplasma in Spain. Acta Hort. 657: 489-494.

Lederer M., SeEmüller E., 1992. Demonstration of mycoplasmas in Prunus species in Germany. J. Phytopathol. 134: 89-96.

Lee I.-M., Bertaccini A., Vibio M., Gundersen D.E., 1995. Detection of multiply phytoplasmas in perennial fruit trees with decline symptoms in Italy. Phytopathol. 85: 728-735.

Lee I.-M. Gundersen D.E., Hammond R.W., Davis R.E., 1994. Use of mycoplasmalike organism (MLO) group-specific oligonucleotide primers for nestedPCR assays to detect mixed-MLO infections in a single host plant. Phytopathol. 84: 559-566.

LeE I.-M. Gundersen-Rindal D.E., Davis R.E., BARTOSZYK I.M., 1998. Revised classification scheme of phytoplasmas based on RFLP analyses of $16 \mathrm{~S}$ rRNA and ribosomal protein gene sequences. Int. J. Syst. Bacteriol. 48: 1153-1169.

Mandic B., Matić S., Al-Rawhanih M., Jelkmann W., Myrta A., 2007. Viruses of sweet and sour cherry in Serbia. J. Plant Pathol. 89(1): 103-108.

Morvan G., 1988. Present status of apricot chlorotic leaf roll in France and surrounding countries. Acta Hort. 209: 169-174.

Myrta A., Ermacora P., Stamo B., Osler R., 2003. Identification of European stone fruit yellows from Japanese plum in Albania. Opt. Meditter. Ser. B 45: 119-121.

Navratil M., Válová P., Fialová R., Petrová K., Fránová J., Nebesářová J., Poncarová-VoráčKová Z., Karešová R., 2001. Survey for stone fruit phytoplasmas in Czech Republic. Acta Hort. 550: 377-382.

Paltrinieri S., Martini M., Stefani E., Pondrelli M., Fideghelli C., Bertaccini A., 2001. Phytoplasma infection in peach and cherry in Italy. Acta Hort. 550: 365-370.

Poggi Pollini C., Bissani R., Ginchedi L., 2001. Occurrence of European stone fruit phytoplasma (ESFYP) infection in peach orchards in NorthernCentral Italy. J. Phytopathol. 149: 725-730.

Rott M.E., JelkmanN W., 2001 a. Characterization and detection of several filamentous viruses of cherry: adaptation of an alternative cloning method (DOPPCR), and modification of RNA extraction protocol. Eur. J. Plant Pathol. 107: 411-420.

Rott M.E., Jelkmann W., 2001 b. Detection and partial characterization of the second Closterovirus associated with Little Cherry Disease, Little Cherry Virus-2. Phytopathol. 91: 261-267.

Sabanadzovic S., Abou Ghanem-Sabanadzovic N., Rowhani A., Grant J.A., Uyemoto J.K., 2005.
Detection of Cherry virus A., Cherry necrotic rusty mottle virus and Little cherry virus 1 in California orchards. J. Plant Pathol. 87: 173-177.

Schneider B., Seemüller E., Smart C.D., KirkPatrick B.C., 1995. Phylogenetic classification of plant pathogenic mycoplasma-like organisms or phytoplasmas. In: R. Razin and J.G. Tully (eds). Molecular Diagnostic Proc. Mycoplasmol.: 369380 .

Seemüller E., Schneider B., 2004. Taxonomic description of 'Candidatus Phytoplasma mali' sp. nov., 'Candidatus Phytoplasma pyri' sp. nov., 'Candidatus Phytoplasma prunorum'sp. nov., the causal agents of apple proliferation, pear decline and European stone fruit yellows, respectively. Intl. J. Syst. Evol. Microbiol. 54: 1217-1226.

Wadley B.N., Nyland G., 1976. Rusty mottle group. In: Virus diseases and non-infectious disorders of stone fruits in North America. US Department of Agriculture, Agriculture Handbook 437: 242-249.

Welsh M.F., Cheney P.W., 1976. Little cherry. In: Virus Diseases and Noninfectious Diseases of Stone Fruit in North America. US Department of Agriculture, Agriculture Handbook No. 437: 231-237.

Zhang Y.P., Kirkpatrick B.C., Di Terlizzzi B., Uyemoto J.K., 2000. Comparison of Cherry green ring mottle virus strains using RT-CR and coat protein sequence phylogeny. J. Plant Pathol. 82: 49-53.

\section{WYSTĘPOWANIE I WYKRYWANIE WYBRANYCH MNIEJ ZNANYCH WIRUSÓW I FITOPLAZM W SADACH DRZEW PESTKOWYCH W POLSCE}

Streszczenie: W 38 sadach drzew pestkowych zlokalizowanych w siedmiu różnych rejonach kraju dokonywano lustracji pod kątem występowania chorób wywoływanych przez mało znane w Polsce wirusy i fitoplazmy. Pobrano liście ze 145 drzew czereśni i 102 drzew wiśni do badań na obecność wirusów drobnienia owoców czereśni (LChV-1 i LChV2), wirusa zielonej pierścieniowej pstrości czereśni (CGRMV), wirusa cętkowanej plamistości liści czereśni (CMLV) i wirusa nekrotyczno-rdzawej plamistości czereśni (CNRMV) przy użyciu metody RT-PCR. Ponadto, testom na CGRMV poddano również 60 drzew brzoskwini i 20 drzew moreli. LChV-1 wykryto w jedenastu drzewach czereśni i trzech drzewach wiśni, zaś CGRMV $\mathrm{w}$ dziesięciu drzewach czereśni, czterech wiśni, czternastu brzoskwini i dwóch moreli. W żadnym z badanych drzew nie stwierdzono obecności LChV-2, CMLV i CNRMV. Stosując PCR z użyciem dwóch par starterów 
uniwersalnych oraz starterów specyficznych na kilka grup fitoplazm, przeprowadzono testy na obecność fitoplazm w 145 drzewach czereśni, 102 drzewach wiśni, 128 drzewach brzoskwini, 37 drzewach moreli, 20 drzewach śliwy i pięciu drzewach nektaryny. Wykazano, że spośród wszystkich badanych, drzewa sześciu czereśni, trzech wiśni, 9 brzoskwini, czterech moreli, trzy drzewa japońskiej śliwy i jedno drzewo nektaryny były porażone przez fitoplazmy. Analiza polimorfizmu długości fragmentów restrykcyjnych (RFLP) po trawieniu enzymami RsaI, MseI, AluI, Ssp I fragmentów 16S rDNA fitoplazm wykazała, że wybrane do badań drzewa były porażone przez dwie różne fitoplazmy zaliczane do grupy fitoplazmy proliferacji jabłoni.

Received March 5, 2010; accepted December 17, 2010 